\title{
Risk-Based Screening Level Analysis and Landfill "Cap" Design of Crude Oil Contaminated Soil Stockpile in Riau Province, Indonesia
}

\author{
I Made Wahyu Widyarsana, Sukandar, and Windy Chyntia Dewi
}

\begin{abstract}
In this study, a crude-oil contaminated stockpile is analyzed to understand the health risks and technical approach in its remediation. The stockpile has an approximate area of 13 hectares, with an approximate volume of $1.300 .000 \mathrm{~m}^{3}$. Relaxed government regulations regarding environmental protection up in 2014 have made stockpiling crude-oil contaminated soils commonplace in Indonesia's oil and gas fields. The stockpile has a flat-shaped landscape, sloping at approximately 10 to 15 degrees, with a varied elevation ranging from 29 meters to 31 meters, peaking at $\mathbf{3 1 . 5}$ meters. This study's objective was to correctly identify the best curative approach to remediate the location to adhere to the Indonesian Government standards and best practices. A landfill "cap" aims to treat the hazardous waste stockpile similar to a typical landfill, though with the absence of the base layer below the stockpile.
\end{abstract}

Index Terms-Landfill capping design, hazardous waste landfill, crude oil contaminated soils, risk-based screening levels.

\section{Procedure AND DATA COLlection}

This study used primary data complemented with secondary data was used to support this study. Primary data was gathered directly in the field and analyzed in a lab. Secondary data was collected through desk research by benchmarking against international best practices and other studies.

Data used in this study is a result of several different field-specific tests as listed below:

1) Topographic survey of the stockpiles

2) Borehole tests: drilling six shallow boreholes of depths up to 10 meters complemented by two deep boreholes of depths up to 30 meters with geotechnical and environmental soil sampling

3) Cone Penetration Tests: 7 CPTs to define the geotechnical parameters for both stockpile and the natural clay immediately beneath

4) Laboratory testing of environmental parameters which include but were not limited to the Toxicity Leaching Characteristic Procedure, TCLP, and soil analysis of Total Petroleum Hydrocarbon, TPH, content

Guided by the data collected, firstly, an interpretation of field survey data and laboratory results was made to determine the waste type of the crude-oil contaminated soil. This is used as a baseline and later on justification of engineering design. COCS was not yet listed as hazardous

Manuscript received April 13, 2020; revised December 1, 2020.

The authors are with Bandung Institute of Technology, Bandung, Indonesia (e-mail: wahyu@ftsl.itb.ac.id, kandar@fts.itb.ac.id, windychyntia@students.itb.ac.id) waste in the Government Regulation No. 101 Year 2014 This process is done through data interpretation from the TCLP tests alongside the CPT tests yielding its TPH content. A geological study was then done in the surrounding environment to determine the characters in geology, such as soil type and water table and permeability, resistivity, and porosity.

As it will later be elaborated, the stockpile's size and volume have proven challenging to displace and be treated directly. In the design process, geological and hydrogeological studies are carried out to identify the lay of land. Then, a health and environmental risk assessment was done in the form of TPH delineation and heavy metal concentrations, which was then compared to the results of the Risk-Based Screening Levels (RBSL) [1] calculations to determine the magnitude of the potential risk posed by the stockpile. Through a site-wide sampling exercise using 13 well-tests, the site-specific characterization results have identified lithology underlying the stockpile to be clay soil with sandy inserts with no visibility of a water table. The lithological permeability value of the hydrocarbon contaminated soil consists of clay with permeability values ranging from $1.2 \times 10-9 \mathrm{~cm} / \mathrm{sec}$ to $1.5 \times 10-6 \mathrm{~cm} / \mathrm{sec}$ and sandy silt with permeability values of $1.1 \times 10-8 \mathrm{~cm} /$ second $1.9 \times 10-6 \mathrm{~cm} /$ second rendering its elemental layer as an aquitard [2]. Total Petroleum Hydrocarbon, TPH, has also been identified through borehole sampling resulting in TPH concentrations being relatively high in the clay soils on the surface with a permeability value of $1 \times 10-6 \mathrm{~cm} / \mathrm{sec}$, concluding low permeability from stockpile surface into the soil beneath. Waste categorization is done to understand the nature of the waste itself through the Toxicity Characteristic Leaching Procedure, TCLP, resulting in $127,500 \mathrm{~m}^{3}$ of soil within stockpile to be hazardous waste. Through soil sampling, it has also been shown that the indigenous soil surrounding the stockpile to be high in Cadmium $(\mathrm{Cd})$ and Chromium $(\mathrm{Cr})$. Within the stockpile itself, Mercury $(\mathrm{Hg})$ and Chromium $(\mathrm{Cr})$ were most abundant. The stockpile's known characteristics were then used to calculate the health risks due to exposure through ingestion, inhalation, and dermal routes. The Total Hazard Index (THI) of the site shows a value of less than 1 . Therefore all exposure routes considered does not show a strong potential in inducing non-carcinogenic effects with Site Specific Target Levels (SSTL) values of $80,196 \mathrm{mg} / \mathrm{kg}, 291,011 \mathrm{mg} / \mathrm{kg}$, and 124,526 $\mathrm{mg} / \mathrm{kg}$ for each exposure route, respectively, with a total SSTL value of $41.777 \mathrm{mg} / \mathrm{kg}$ (4.18\%). Total Petroleum Hydrocarbon (TPH) as the main contaminant of concern was also measured for its concentration and compared to the 
SSTL levels to estimate the degree of contamination.

The methodology used to carry out this study was a modified interpretation of the typical waste landfill model. At the time of this study, there was little to no reference to modified landfill structures and their Indonesia implementation. Beyond the engineering challenges, hurdles in regulatory aspects were also encountered. The subject of this study, COCS, was an unfamiliar waste in the Indonesian waste management system. It is not a commonplace hazardous waste, resulting in a lack of regulatory guides and implementation references. Therefore, the methodology of this study relies heavily on interpretation of international experiences such as the American Petroleum Institute [3], The American Society for Testing and Materials, and local government regulation, namely Government Regulation No. 101 Year 2014 [4] about Hazardous Waste Management, Government Regulation No. 63 Year 2016 [5] on Hazardous Waste Landfilling Procedures and the US EPA's Review of Liner and Cap Regulations for Landfills [6].

\section{FIELD OBSERVATIONS}

This study's engineering design will be referred to as a landfill" cap" due to the absence of the elementary bottom layer, which would be found in a typical landfill. This approach's main reasoning is the massive $1.300 .000 \mathrm{~m} 3$ area of the stockpile, which will be costly to displace and replace to layout an elemental layer, so soil displacement will also potentially cause environmental disruption and contamination. This assumption will, later on, be corroborated by field data to justify the approach further.

In designing a cap for the COCS stockpile, field characterization is essential to comprehensively understand the local geological and geomorphological conditions on top of waste characterization. Government Regulation No. 101 Year 2014, the standard of which hazardous waste management practices are based on this study, is used. The fifth appendix of the regulation states that crude oil fractions are categorized into two tranches, C6-C9 and C10-C36 petroleum hydrocarbon. Internal wells were put in place within the stockpile to measure TPH concentration, with one well outside of the study perimeter as a baseline.

Analysis of the well-test results yielded a TPH of the C6-C9 fractions to be $568 \mathrm{mg} / \mathrm{kg}$ and of the C10-C36 to be $10500 \mathrm{mg} / \mathrm{kg}$. A model for the spread in concentration for these two fractions are modeled through Fig. 2 and Fig. 3.

TPH concentrations are a useful indicator of petroleum contamination in a specific location. Crude oils can vary in how many permutations of hydrogen-carbon chemicals they contain. Therefore TPH is used as a collective measure in providing a sense of joint concentration.

The two tranches of TPH concentration values are tested to comply with the Government Regulation No. 101 Year 2014 as it is defined in Annex V. In conclusion, according to the concentrations of TPH and the corresponding regulation, the COCS stockpile is concluded to contain $127.500 \mathrm{~m}^{3}$ of Category II hazardous waste.

In the Indonesian Government Regulation No. 101 Year 2014, hazardous waste is divided into two categories. Category I calls for wastes that are flammable, reactive, infectious, and corrosive. Category II is defined as hazardous waste that is determined through Toxicity Leaching Characteristic Procedure (TCLP) test and/or LD50 toxicology tests and/or a sub-chronic toxicology test.

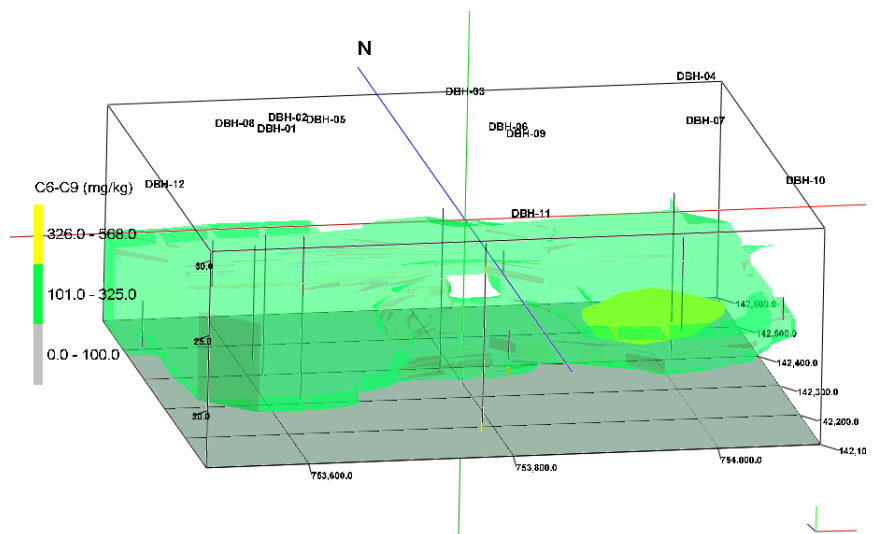

Fig. 1. Crude oil contaminated soil dispersion of C6-C9 fraction.

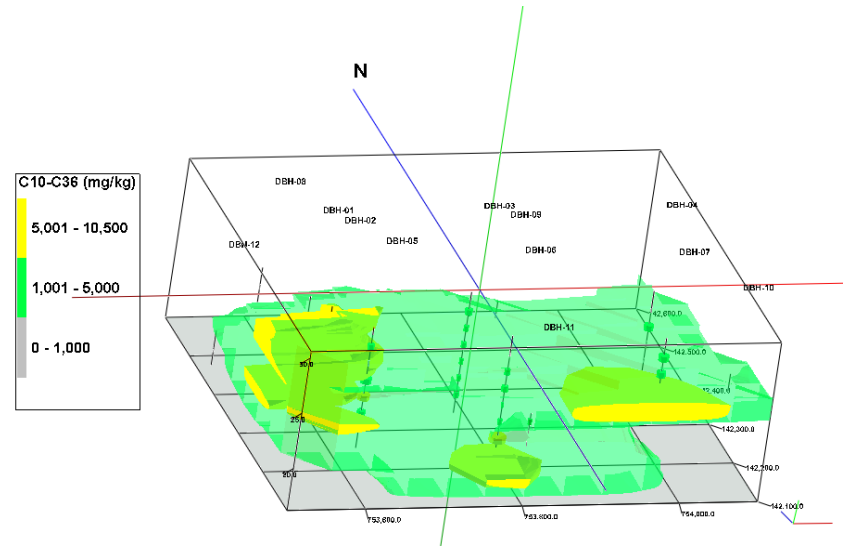

Fig. 2. Crude oil contaminated soil dispersion of C9-C36 fraction.

The TCLP test was carried out in this study to simulate the COCS leaching potential in the landfill. The test procedure follows the US EPA 1311 test method as its primary reference. The test specimen was the COCS with its solid phase extracted with a leaching substance, glacial acetic acid, or carbonic acid, 20 times its weight. The mixture will become uniform through agitation and is ready for both TPH content analysis and heavy metal parameters such as As, Ba, $\mathrm{Be}, \mathrm{B}, \mathrm{Cd}, \mathrm{Co}, \mathrm{Cr}, \mathrm{Cu}, \mathrm{Pb}, \mathrm{Hg}, \mathrm{Mo}, \mathrm{Ni}, \mathrm{Ag}$, and $\mathrm{Zn}$. Inorganic heavy metal parameters are exclusively used due to the low concentration of the C1-C6 TPH fraction. Low volatile contents indicate low organic contents; therefore, chances of contamination from organic heavy metals as a pollutant to be negligible.

Results of the TCLP tests were then matched to the tranches defined as Category A and Category B by the same regulation. Heavy metal testing was done in the same manner, in 11 test points within the stockpile with one additional well test as a baseline. A sample result from one test point within the stockpile is shown in Table I. It is to be understood that the well-test results follow a similar pattern.

Prominent heavy metals noted in high concentration is Chromium (Cr) and Mercury (Hg). It was found that the total concentration of the $\mathrm{Cr}$ parameter at all well-test points has a value between TK-B and TK-C, which indicates that all COCS samples collected from each location are categorized as non-hazardous waste. When comparing the $\mathrm{Cr}$ levels against the baseline, it is clear that the virgin soil is high in $\mathrm{Cr}$. 
Mercury concentrations have also led to the conclusion as the soil being categorized as non-hazardous waste due to its concentration between TK-C at $0,3 \mathrm{mg} / \mathrm{kg}$ and TK-B at 75 $\mathrm{mg} / \mathrm{kg}$.

TABLE I: SAMPLE RESUlt FOR HeAvy METAL TESTING WithiN STOCKPILE

\begin{tabular}{|c|c|c|c|c|c|c|c|c|}
\hline \multirow{2}{*}{ Heavy Metal } & \multirow{2}{*}{ Unit } & Baseline & \multicolumn{5}{|c|}{ Test Point 1} \\
\cline { 3 - 9 } & $3 \mathrm{~m}$ & $1.5 \mathrm{~m}$ & $3 \mathrm{~m}$ & $4.5 \mathrm{~m}$ & $6 \mathrm{~m}$ & $7.5 \mathrm{~m}$ & $9 \mathrm{~m}$ \\
\hline Antimony & $\mathrm{mg} / \mathrm{kg}$ & $<5.00$ & $<5.00$ & $<5.00$ & $<5.00$ & $<5.00$ & $<5.00$ & $<5.00$ \\
\hline Arsenic & $\mathrm{mg} / \mathrm{kg}$ & 1.66 & 1.9 & 5.16 & 1.1 & 1.54 & $<1.00$ & 1.08 \\
\hline Barium & $\mathrm{mg} / \mathrm{kg}$ & 23.4 & 140 & 81.2 & 55.4 & 21.4 & 52.1 & 21.4 \\
\hline Beryllium & $\mathrm{mg} / \mathrm{kg}$ & 1.04 & $<1.00$ & $<1.00$ & $<1.00$ & $<1.00$ & $<1.00$ & $<1.00$ \\
\hline Boron & $\mathrm{mg} / \mathrm{kg}$ & $<5.00$ & $<5.00$ & $<5.00$ & $<5.00$ & $<5.00$ & $<5.00$ & $<5.00$ \\
\hline Cadmium & $\mathrm{mg} / \mathrm{kg}$ & 5.63 & $<1.00$ & $<1.00$ & $<1.00$ & $<1.00$ & $<1.00$ & $<1.00$ \\
\hline Chromium & $\mathrm{mg} / \mathrm{kg}$ & 9.81 & 21.2 & 41.6 & 13.2 & 9.32 & 11.1 & 5.61 \\
\hline Copper & $\mathrm{mg} / \mathrm{kg}$ & 7.47 & 2.7 & 4 & 2.1 & 4.64 & 1.52 & 2.81 \\
\hline Lead & $\mathrm{mg} / \mathrm{kg}$ & 9.48 & 10.4 & 12.3 & 7.94 & 8.35 & 8.97 & 4.64 \\
\hline Manganese & $\mathrm{mg} / \mathrm{kg}$ & 1220 & 24.3 & 31.1 & 18.5 & 12.2 & 20.2 & 40.4 \\
\hline Mercury & $\mathrm{mg} / \mathrm{kg}$ & $<0.05$ & 0.33 & 0.32 & 0.32 & 0.16 & 0.07 & $<0.05$ \\
\hline Molybdenum & $\mathrm{mg} / \mathrm{kg}$ & $<1.00$ & $<1.00$ & $<1.00$ & $<1.00$ & $<1.00$ & $<1.00$ & $<1.00$ \\
\hline Nickel & $\mathrm{mg} / \mathrm{kg}$ & 12.3 & 6.61 & 6.18 & 3.66 & 2.07 & 6.3 & 6.94 \\
\hline Selenium & $\mathrm{mg} / \mathrm{kg}$ & $<1.00$ & $<1.00$ & $<1.00$ & $<1.00$ & $<1.00$ & $<1.00$ & $<1.00$ \\
\hline Silver & $\mathrm{mg} / \mathrm{kg}$ & $<1.00$ & $<1.00$ & $<1.00$ & $<1.00$ & $<1.00$ & $<1.00$ & $<1.00$ \\
\hline Vanadium & $\mathrm{mg} / \mathrm{kg}$ & 13 & 42.1 & 74.8 & 22.2 & 18.6 & 17.6 & 6.53 \\
\hline Zinc & $\mathrm{mg} / \mathrm{kg}$ & 55.1 & 13.8 & 17.6 & 9.28 & 7.68 & 17.2 & 31.8 \\
\hline
\end{tabular}

In summary, from all 12 well-test points, prominent heavy metals found was to be Chromium and Mercury with a maximum concentration of $45,5 \mathrm{mg} / \mathrm{kg}$ against its $9,81 \mathrm{mg} / \mathrm{kg}$ baseline and $0,59 \mathrm{mg} / \mathrm{kg}$ against its $0,05 \mathrm{mg} / \mathrm{kg}$ benchmark, respectively. A physical model of both heavy metals and their dispersion throughout the stockpile could be found in Fig. 4 and 5 .

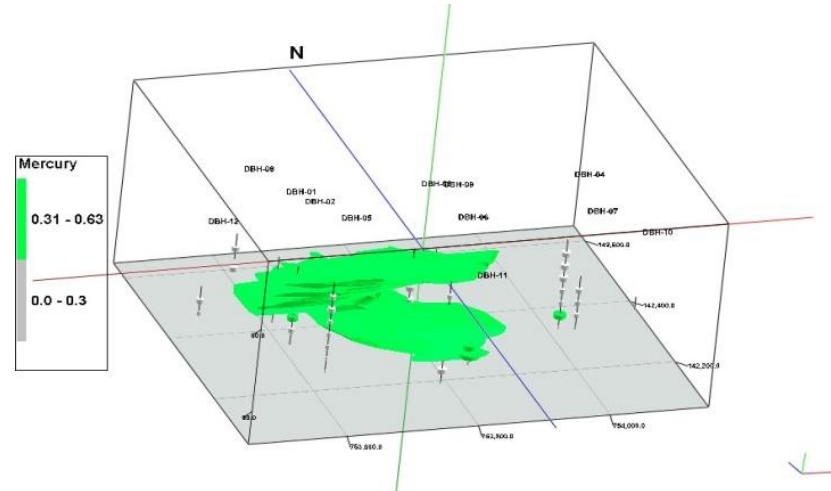

Fig. 3. Mercury spread within the stockpile.

A complete assessment of the site was then done by combining data collected concerning the waste constituent complemented with data from the surrounding soil area. Primary data was gathered through log lithology drilling superimposed with the geoelectricity identification for six cross-sections of the area, with a total of 12 testing wells. It was found that the lithology underlying the COCS was dominated by clay with sandy silt inserts, with no water table visible up to 25 meters below the COCS.

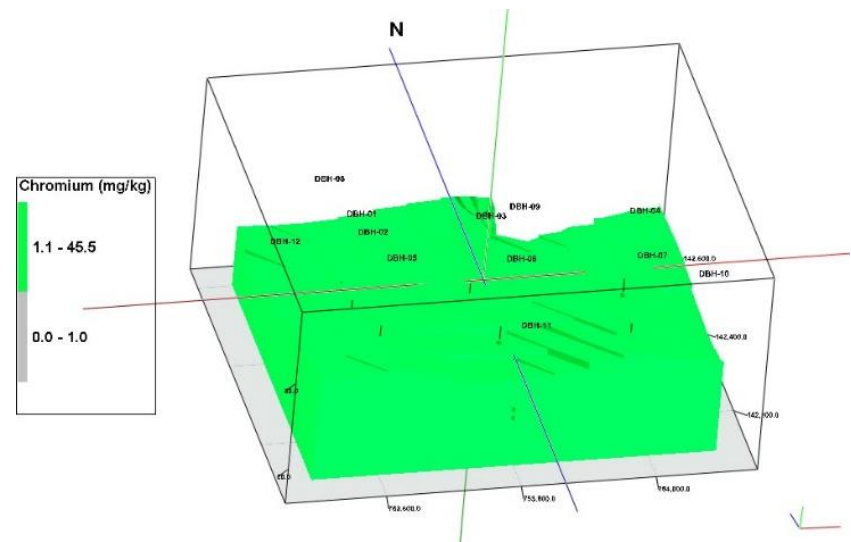

Fig. 4. Chromium spread within the stockpile.

It was found from the soil samples that the lithological permeability value of the hydrocarbon contaminated soil consists of clay with permeability values ranging from $1.2 \times 10-9 \mathrm{~cm} / \mathrm{sec}$ to $1.5 \times 10-6 \mathrm{~cm} / \mathrm{sec}$ and sandy silt with permeability values of $1.1 \times 10-8 \mathrm{~cm} /$ second $1.9 \times 10-6$ $\mathrm{cm} /$ second. The underlying soil was also sampled and yielded as a clay with a permeability below $10^{-5} \mathrm{~cm} / \mathrm{sec}$, indicating that it is incapable of transmitting water or any other heavy contaminants upon contact.

\section{CAlculations}

Beyond data collection through site-sampling, two empirical parameters were then calculated as a predictor base to determine the potential danger of containment implementation activities. Parameters calculated include the value of the Site-Specific Target Level, SSTL, which values the maximum concentration allowed for no significant hazard to occur in the environment specifically in receptors through humans, and the calculation of the Total Hazar Index (THI) value which represents the hazard yielded from each total petroleum fraction. A risk-based clean-up approach is made by performing these human health risk assessments.

In conducting this assessment, the methodologies used are based on the United States Environmental Protection Agency methods, which are commonly used, supplemented by empirical formulas by the American Society for Testing and Materials (ASTM) [7]. In calculating these values, which will be based on safety evaluation in this specific stockpile site, site-specific variables must be identified. The stockpile site is located in a remote area with a distance to the nearest anthropogenic settlement of 2 to 6 kilometers. Therefore it is inferred that the respondents potentially exposed to the stockpile contaminants are mainly workers and those with considerable distance between the stockpile and the settlement. It is safe to assume that workers will not be required to stay as residents within the stockpile site. Therefore each worker will spend an average of three days in one week, 165 days in a year, to run monitoring and control evaluation activities at the stockpile site. Beyond these assumptions, further assumptions that could be of use include:

\section{- Exposure Route}

The route of exposure is the "how" hazardous waste could potentially impact human health. Among the routes of exposure from polluted hydrocarbon soils include oral, 
inhalation, and dermal contact. These exposure routes will be the assumption base for this study.

- Average Weight of Receptor

Activities within the stockpile area, which include monitoring, evaluation, maintenance, and emergencies, will require workers to enter the site and increase the potential of exposure. These workers will be considered the primary receptors of hazardous waste exposure with an average body weight of $57,7 \mathrm{~kg}$, which is assumed to be the Asian race adult human average body weight [8].

\section{- Exposure Duration}

This stockpile construction will require dedicated resources responsible for this massive environmental project, from design and implementation to monitoring and evaluation. The Indonesian average working duration is 32 years, starting from the average university graduation at 22 years to the average retirement age of 54 years (Indonesian Statistic Bureau, 2018). Assuming the maximum duration of exposure, this value will be adapted.

\section{- $\quad$ Reference Dose}

Reference Dose is determined by The American Petroleum Institute, which constitutes a variable used in calculations to calculate exposure through each route for each Total Petroleum Hydrocarbon fraction.

Assumptions within this analysis follow the United States US EPA Risk-Based Screening Levels and are shown in Table II
TABLE II: RISK-BASED SCREENING LEVEL GENERAL UNITS AND ASSUMPTIONS USED (US EPA, RISK ASSESSMENT GUIDANCE FOR SUPERFUnd VOLUME I: HuMAN HEALTH EVALUATION MANUAL, 2004)

\begin{tabular}{|c|c|c|c|}
\hline Parameter & Symbol & Unit & Value \\
\hline $\begin{array}{c}\text { Average } \\
\text { Non-Carcinogenic } \\
\text { Exposure Time }\end{array}$ & - & Years & 32 \\
\hline $\begin{array}{c}\text { Average Receptor } \\
\text { Weight }\end{array}$ & BWW & $\mathrm{Kg}$ & 57,7 \\
\hline Exposure Duration & EDW & Years & 32 \\
\hline $\begin{array}{c}\text { Exposure } \\
\text { Frequency }\end{array}$ & EFW & Days/Year & 365 \\
\hline $\begin{array}{c}\text { Exposure Time to } \\
\text { Outdoor Air }\end{array}$ & ETW & Hours/day & 8 \\
\hline Soil Ingestion rate & IRW & Mg/Day & 100 \\
\hline $\begin{array}{c}\text { Outdoor Air } \\
\text { Inhalation Rate }\end{array}$ & - & $\mathrm{M} 3 /$ Day & 31 \\
\hline $\begin{array}{c}\text { Soil to Skin } \\
\text { Adherence Factor }\end{array}$ & AFW & mg/cm2 & 0,2 \\
\hline $\begin{array}{c}\text { Surface Area of } \\
\text { Skin Used for Soil } \\
\text { Exposure }\end{array}$ & SAW & Cm2/Day & 4100 \\
\hline
\end{tabular}

The Screening Level value is calculated to determine whether an action should be taken against a particular polluted site. This method facilitates the identification of contaminants and areas of exposure that require attention and or remediation measures. This value is calculated using the assumption of the most critical condition, the worst-case scenario, by choosing the highest TPH data of $3.63 \%$. The conversion between fractionated crude oil values into Total TPH values are listed in Table III regarding the weight-average method outlined in the TPH Criteria Working Group Study [9].

TABLE III: FRACTIONATION OF CRUDE OIL PRODUCTION IN STOCKPILE OPERATION AREA

\begin{tabular}{|c|c|c|c|c|c|}
\hline Hydrocarbon Chain & Unit & Stockpile Value & Diesel Value & Gasoline Value & Baby Oil Value \\
\hline$>5$ - 6C Alifatik & \multirow{13}{*}{$\mathrm{mg} / \mathrm{kg}$} & & & & \\
\hline$>6-8 \mathrm{C}$ Alifatik & & 2300 & 3900 & 240000 & \\
\hline$>8-10$ C Alifatik & & 10000 & 17000 & 15000 & \\
\hline$>10-12$ C Alifatik & & 15000 & 32000 & 14000 & \\
\hline$>12-16$ C Alifatik & & 39000 & 150000 & 2100 & 16000 \\
\hline$>16-44$ C Alifatik & & 120000 & 320000 & 820 & 840000 \\
\hline$>6$ - 7 C Aromatic & & & & 7900 & \\
\hline$>7-8$ C Aromatic & & & 260 & 37000 & \\
\hline$>8-10 \mathrm{C}$ Aromatic & & 540 & 4300 & 98000 & \\
\hline$>10-12$ C Aromatic & & 2600 & 14000 & 26000 & \\
\hline$>12-16 \mathrm{C}$ Aromatic & & 18000 & 86000 & 3500 & 180 \\
\hline$>16-21 \mathrm{C}$ Aromatic & & 31000 & 100000 & 1200 & 1500 \\
\hline$>21-44 \mathrm{C}$ Aromatic & & 88000 & 28000 & 360 & 7700 \\
\hline
\end{tabular}

The TPH component of petroleum is evaluated in terms of the "carbon range" of aliphatic and aromatic compounds. The carbon range is defined by groups of aliphatic or aromatic compounds that exhibit similar physiochemical and toxicological characteristics. These carbon groups are determined to make it easier to characterize and analyze these fractions concerning pollution by TPH. The compounds included in the $\mathrm{C} 5-\mathrm{C} 8$ aliphatic carbon range are the most volatile, although $\mathrm{C} 9-\mathrm{C} 12$ aliphatic and $\mathrm{C} 9-\mathrm{C} 10$ aromatics are also included in this category. Compounds belonging to the aromatic carbon ranges $\mathrm{C} 13-\mathrm{C} 18$ and $\mathrm{C} 11-\mathrm{C} 22$ are considered "semi-volatile." Aliphatic compounds with more than 18 carbon atoms and aromatic compounds with more than ten carbon atoms are not regarded as volatile.

Values such as the Hazard Quotient (HQ), Total Hazard Index (THI), Risk-Based Screening Levels (RBSL), and Site-Specific Target Levels (SSTL) are calculated to characterize the maximum exposure acceptable to humans, in this case, workers at the stockpile site, as an indication as to what preventive measures could be carried out to protect or reduce the amount of exposure that is received by these receptors.

Petroleum components within the contaminated soils are complex made up of hundreds of different compounds consisting of hydrogen and carbon, which have become hydrocarbons. The compounds could collectively be grouped 
into either aromatic or aliphatic carbon ranges based on the number of atom carbons in each compound. The Total Hazard Index is determined through the ratio of the TPH aliphatic fraction to the aromatic fraction.

TABLE IV: TOTAL PETROLEUM HYDROCARBON FRACTION ESTIMATION WITHIN STOCKPILE

\begin{tabular}{|c|c|}
\hline TPH Fraction & Concentration $(\mathrm{mg} / \mathrm{kg})$ \\
\hline \multicolumn{2}{|l|}{ Aliphatic: } \\
\hline$>6-8$ C Aliphatic & 255,79 \\
\hline$>8-10$ C Aliphatic & $1.112,15$ \\
\hline$>10-12$ C Aliphatic & $1.668,22$ \\
\hline$>12-16$ C Aliphatic & $4.337,38$ \\
\hline$>16-44$ C Aliphatic & $13.345,79$ \\
\hline \multicolumn{2}{|l|}{ Aromatic: } \\
\hline$>8-10 \mathrm{C}$ Aromatic & 60,06 \\
\hline$>10-12$ C Aromatic & 289,159 \\
\hline$>12-16 \mathrm{C}$ Aromatic & $2.001,87$ \\
\hline$>16-21 \mathrm{C}$ Aromatic & $3.447,70$ \\
\hline$>21-44$ C Aromatic & $9.786,90$ \\
\hline$\sum$ Concentration of Aliphatic TPH & $20.719,30$ \\
\hline$\sum$ Concentration of Aromatic TPH & $15.585,70$ \\
\hline
\end{tabular}

The Hazard Quotient value is then the ratio between potential exposure against pollutant constituents at a certain level with zero expectations of harmful effects. An HQ value of less than or equal to one indicates that the impact on non-cancerous hazards is of no great potential and low probability of occurrence. The HQ value is a testament of whether or not a risk could occur and the potential it may impose concerning each pollutant. The Hazard Quotient is then calculated using the formula:

$$
\text { Hazard Quotient }=\frac{\text { Average Daily Dose }}{\text { Reference Dose }}
$$

The Average Daily Dose used in this calculation is the value of which the receptors receive the average daily dose of pollutants. This is referenced to the Reference Dose value, a set of baseline values commonly used by the Superfund Health Risk Technical Support Centre, United States Environmental Protection Agency as the maximum dose of exposure to pollutant constituents without causing significant and long-term damage to the recipient. The value of the average daily dose varies depending on several variables, which follows the equation below:

$$
\begin{aligned}
& \text { Average Daily Dose } \\
& \text { Chemical Concentration }\left(\frac{m g}{k g} \text { soil }\right) * \\
& \text { Rate of Exposure }\left(\frac{\mathrm{mg}}{\mathrm{day}}\right) * \\
& \text { Exposureduration }(\text { years }) * \\
& =\frac{\text { Frequencyof exposure }\left(\frac{\text { days }}{y e a r}\right)}{\text { Body Weight of Receptor }(\mathrm{kg}) *} \\
& \text { Average Time of Exposure (days) }
\end{aligned}
$$

Through these calculations of the daily average exposure dose against the reference dose, it is now possible to calculate the Hazard Index due to aggregating the Hazard Quotient Value. The Hazard Quotient value is calculated based on each pollutant constituent's concentration, in this case, on each trench of the TPH fraction concentration concerning the exposure route and exposure duration. This calculation is done to assess the overall maximum dose and exposure hazard threshold, which is acceptable to the receptor. Thus, the Hazard Quotient values' aggregation from each TPH faction concentration will result in the Hazard Index value. An aggregation of each Hazard Index for each respective exposure route, whether ingestion, inhalation, or dermal contact, will result in the maximum value of which the receptor can withstand exposure with no serious consequence. An aggregated Total Hazard Index value below one will indicate the likelihood of adverse effects on non-cancerous health risks are unlikely to occur and could be addressed less severely. Should the Total Hazard Index value be greater than or equal to 1 , it would be safe to assume that the severity of the impact from exposure is more than likely to occur but will indefinitely depend on the variable duration of exposure, among other things. The Total Hazard Index value could be calculated using the following equation:

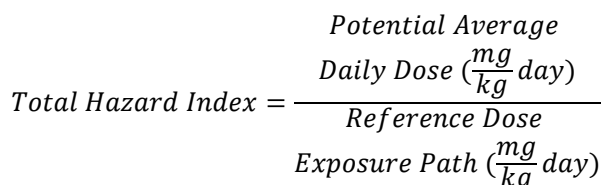

Risk-Based Screening Levels and Site-Specific Screening Levels are then calculated as another empirical approach to obtain both risk-based concentration screening level values for specific pollution sites and the maximum limit of concentration of pollutants allowed within site. These values are calculated for the exposure route, which is then aggregated to obtain the site-wide values.

$$
\begin{gathered}
\text { Non - Carcinogenic Screening Level }\left(\frac{m g}{\mathrm{~kg}}\right)= \\
\frac{\text { Total Hazard Quotient } *}{\text { Receptor Body Weight }(\mathrm{kg}) * \text { Average Exposure Time (days) }} \\
\frac{1}{\text { Reference Dose } *} \\
\frac{10^{-6} \mathrm{~kg}}{\mathrm{mg}} * \\
\text { ESTL }\left(\frac{\mathrm{mg}}{\mathrm{kg}}\right)=\frac{\text { Exposure Frequency }\left(\frac{\text { day }}{\text { year }}\right) *}{\Sigma\left(\frac{\text { Total Hazard Index }}{\text { Screening Level Non-Carcinogenic Value }\left(\frac{\mathrm{mg}}{\mathrm{kg}}\right)}\right)} \\
\text { TABLE V: SSTL VALUES FOR EACH CHOSEN EXPOSURE RoUTE }\left(\frac{\mathrm{mg}}{\mathrm{day}}\right)
\end{gathered}
$$

\begin{tabular}{|c|c|c|}
\hline Exposure Route & $\begin{array}{c}\text { SSTL Value } \\
(\mathrm{mg} / \mathrm{kg})\end{array}$ & $\begin{array}{c}\text { SSTL Value } \\
(\%)\end{array}$ \\
\hline Ingestion & 47,9219 & 4,79 \\
\hline Inhalation & 364,734 & 36,47 \\
\hline Dermal & 105,254 & 10,52 \\
\hline Total & 30,203 & 3,019 \\
\hline
\end{tabular}

Following the calculation methods detailed above, SSTL values for each chosen exposure route was then found to be as follows in Table VIII. SSTL values for a given exposure path and contaminant represent a concentration in the affected 
medium that protects a human or ecological receptor located at a relevant point of exposure.

\section{RESUlTS AND CONCLUSIONS}

Empirical results show that the total Total Hazard Index values show for all respective exposure routes to value less than and equal to 1, explaining that these exposure routes may be the possibility of not imposing carcinogenic effects to the receptors [10]. SSTL values for soil ingestion, inhalation and dermal contact exposure routes are found to be 47.9219 mg.kg, $364.734 \mathrm{mg} / \mathrm{kg}$, and $105.254 \mathrm{mg} / \mathrm{kg}$, respectively. To obtain a multi-exposure SSTL value, a weighted aggregation was done to each exposure route resulting in a value of $30.203 \mathrm{mg} / \mathrm{kg}$ (3.019\%) within the stockpile area.

Furthermore, a descriptive analysis shown in Table VI on the TPH concentration within the stockpile has been done to present, and corroborate field sampling results shown in Table VII, that TPH concentration values are relatively small $(<1 \%)$. The highest TPH concentration was found at the 7 th testing point at a depth of 4.5 to 5 meters above the ground surface, a TPH concentration of $1,07 \%$.

TABLE VI: DESCRIPTIVE STATISTICS OF TPH CONCENTRATION

\begin{tabular}{|c|c|}
\hline Descriptive Statistic Analysis & Descriptive Statistic Analysis \\
\hline Average & $0,21 \%$ \\
\hline Standard Deviation & $0,24 \%$ \\
\hline Maxiumum Value & $1,07 \%$ \\
\hline Total Sample & 59 \\
\hline
\end{tabular}

TABLE VII: CUMULATIVE FREQUENCY OF TPH CONCENTRATION

\begin{tabular}{|c|c|c|}
\hline TPH & Total Sample & Percentage \\
\hline$>0 \%$ & 59 & $100 \%$ \\
\hline$<1 \%$ & 58 & $98,31 \%$ \\
\hline$<2 \%$ & 59 & $100 \%$ \\
\hline
\end{tabular}

Regarding the 12 testing points done in the stockpile area, not one particular point within the stockpile had a TPH concentration that exceeded the total SSTL value coupled with the assumption that workers will work three days a week, it is concluded that the impacts from hazardous waste exposure through ingestion, inhalation, and dermal contact is negligible. Though concluded to result in minor receptor damage empirically, preventive measures, such as protective gear, are always advised when operating in areas of risk.

Based on the hazardous waste exposure potential analysis regarding worker safety, coupled with site-characterization and identification through geophysical analysis, it was then concluded that the design and construction of a landfill cap within these circumstances to be possible and viable as a remediation option. The cap's design followed the Indonesian Government Regulation No. 63 Year 2016 regarding landfills and construction. With reference to this regulation and the ASTM best practice guidelines, it was then technically formulated for the cap to adhere to specific technical requirements, shielding workers and those coming across the stockpile from potential danger due to hazardous waste exposure.

Pertinent factors to be considered in designing landfill "caps," especially those relating to the structure of the cap itself and the surrounding environment as a whole, include, but are not limited to, the stability of materials used to construct the infrastructure. The structure of the landfill cap and its technical assignments are as follows. With reference to international standards calibrated with the Indonesian Ministry of Environmental and Forestry Regulation No. 63 Year 2016 are as follows:

- $\quad$ Land Cover Intermediaries

Intermediaries in the form of soil with a thickness of no less than 15 centimeters is placed above the hazardous waste stockpile. In principle, the primary layer above the waste consists of hydrophobic and hydrophilic cover layers. The compacted clay layer will cover the geomembrane layer's shortcomings while the geomembrane layer protects the clay layer. This concept aims to be efficient and tolerant of practical errors in the convective flow of water or gas and the diffusion of all types of pollutants. The intermediate soil cover becomes the first layer proposed to be used as an intermediary, piled directly on the hazardous waste with a thickness of at least 15 centimeters. The intermediate layer is useful as the first insulation layer. Directly above this first layer, a barrier clay soil compacted or geosynthetic clay liners is used as the next insulator.

\section{- Barrier Hoods}

In the form of clay soil, compacted to reach hydraulic conductivity of $10^{-7} \mathrm{~cm} / \mathrm{sec}$ with a thickness of 60 centimeters, or in the form of a Geosynthetic Clay Liner layer with a thickness of 6 centimeters. In this case, clay, or GCL layer, is useful to prevent contaminants from reaching the layers below through infiltration; therefore, this layer needs to meet the hydraulic conductivity specifications of $10^{-7} \mathrm{~cm} / \mathrm{seconds}$. In the absence of clay soil, GCL is used. Although the GCL layer is prone to shearing from tears due to penetration of plant roots, the GCL possesses better elasticity than clay soils, making it possible for GCL layers to recover from deformation due to burden.

\section{- Geomembrane Hoods}

In the form of HDPE with a thickness of at least 1 millimeter with a hydraulic conductivity of $10-7 \mathrm{~cm} / \mathrm{sec}$ and must be designed to withstand all stresses during installation, upper layer construction, and closing final filling facilities. Geomembranes used for settling layers in a waste collection system must meet the specifications' requirements, namely to prevent leakage not to pollute the surrounding environment. Geomembranes must be made from high-quality fresh and pure, high-quality synthetic polymer HDPE material, not from recycled products, which are about 97.5\% HDPE and $2.5 \%$ carbon black material, without using additives, anti-oxidants, and heat stabilizers. The quality of the polymer must be certified and specific for geomembrane applications.

The geomembrane must have resistance to the influence of chemicals present in the waste and other microbiological impacts. Geomembranes must have high characteristic qualities and impermeability characterized by minimal permeability values. Table VII references standard best practices, as stated by The American Society for Testing and Materials are listed.

- Vegetation

The top layer of the hood construction is a layer of vegetation that is useful for creating a barrier against external aggressors and acts as a water catchment area for rainfall. A landfill "cap" was designed to suit the stockpile structure through data interpretation and calculation of both primary and secondary data. Leveling through the addition of clay soil 
mixture to level the stockpile was done before the cap's layering. A sample cut of the stockpile structure is as follows: a height ratio of $1: 1000$ and a volume ratio of $1: 1000$. A detailed engineering drawing of the cap is enclosed to provide further details in Fig. 7.

TABLE VIII: TECHNICAL SPECIFICATIONS AS MINIMUM REQUIREMENTS FOR GEOMEMBRANES

\begin{tabular}{|c|c|c|c|}
\hline \multicolumn{2}{|c|}{\begin{tabular}{|l|l|} 
No Aspect \\
\end{tabular}} & \multirow{2}{*}{\begin{tabular}{|l|} 
Physical Value \\
$1,5 \mathrm{~mm}$
\end{tabular}} & \multirow{2}{*}{$\begin{array}{l}\text { Standard Reference } \\
\text { ASTM D } 5199\end{array}$} \\
\hline 1 & Minimum thickness & & \\
\hline 2 & Allowable thickness variation & $\leq 5 \%$ & ASTM D 5199 \\
\hline 3 & Density & $0,94 \mathrm{gram} / \mathrm{cm} 3$ & $\begin{array}{l}\text { ASTM D } 792 \text { or } \\
1505\end{array}$ \\
\hline 4 & Melt Flow Index & $\begin{array}{l}\geq 2 \text { gram } / 10 \\
\text { minute }\end{array}$ & ASTM 1238 \\
\hline 5 & Tensile strength at yield & 25 Newton/mm & ASTM D 6693 \\
\hline 6 & Elongation at yield & $12 \%$ & ASTM D 6693 \\
\hline 7 & Black carbon Constituent & $2 \%$ & ASTM 1603-94 \\
\hline 8 & Tear Resistance & 200 Newton & ASTM D 1004 \\
\hline 9 & Puncture Resistance & $\geq 500$ Newton & ASTM D 4833 \\
\hline & $\begin{array}{l}\text { Stability in storage (1 hour/ } 10 \\
\text { C) }\end{array}$ & $\leq 2 \%$ & ASTM D 1204 \\
\hline & Rol material width & $\geq 8$ Meter & ASTM D 1593 \\
\hline
\end{tabular}

The fill-only approach in this design is carried out through leveling through an addition of clay soil directly on top of the stockpile. This approach was settled on instead of a cut-and-fill approach considering the risks of the displacement of the hazardous waste stockpile. Workers and the surrounding environment will be at risk of hazardous waste exposure in any case. Another alternative that was not chosen as the implemented design is constructing a cap that varies in-depth, following the stockpile's natural elevation. This design was deemed inefficient in construction since the cap must be segmented into more than many segments following the varying heights from 0,5 meters to 21 meters. Not only challenging in terms of construction, the sustainability of a varied height cap was questioned as the dips and climbs could be prone to shearing and tearing on top of flooding risks due to puddling of rainwater. In the chosen fill-only design alternative, the cap has been constructed with a slope of 1:4 to ensure the cap can channel rainwater into the surrounding drainage infrastructure and to prevent the possibility of erosion. While it is not designed here, a drainage system is crucial to redirect the water flow further.

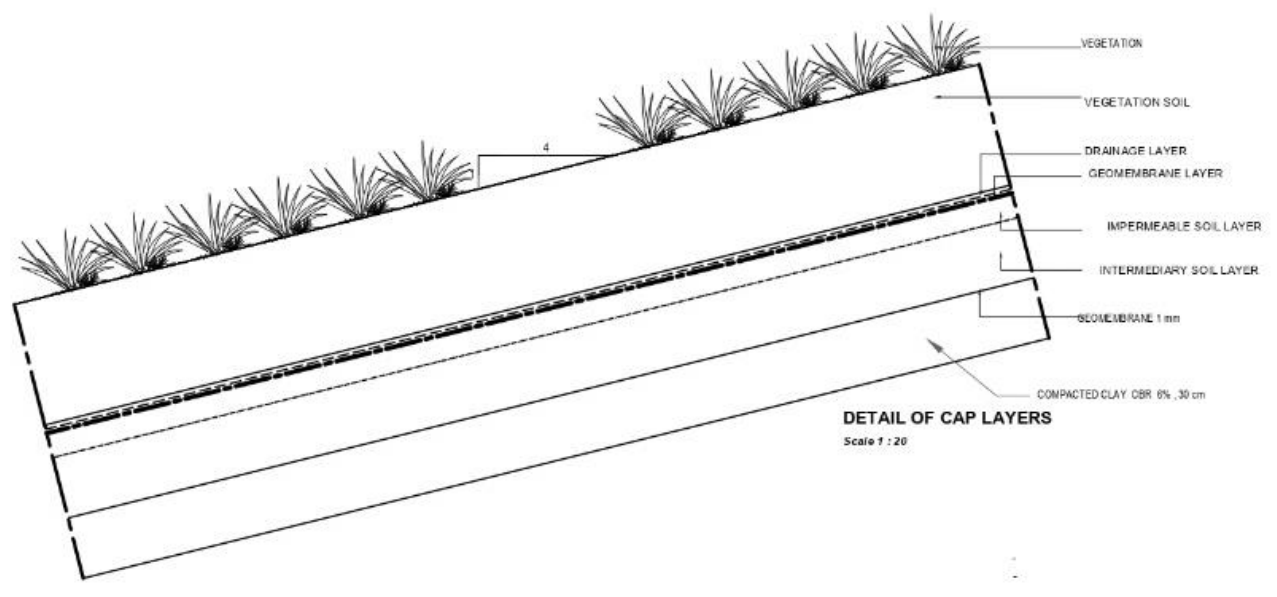

Fig. 5. Landfill cap layers in detail.

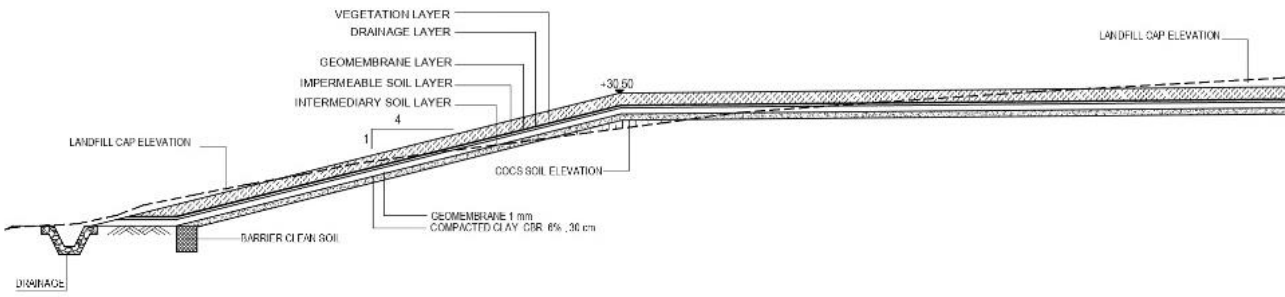

LANDFILL CAP DETAIL, SAMPLE CROSS SECTION

SCAlo 1: 200

Fig. 6. Landfill cap cross-section in detail.

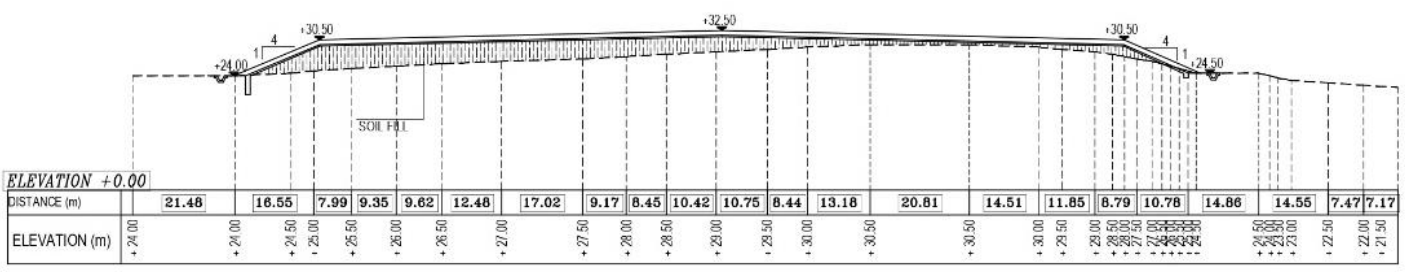

CAPPING CROSS SECTION SAMPLE

SCALE $H=1: 1000, V=1: 1000$

Fig. 7. Landfill cap layers in detail. 


\section{CONCLUSION}

1) Hydrocarbon-contaminated soil in the Riau province stockpile has a thickness ranging from 0.5 to 21-meters, which is spread irregularly to the stockpile's outer boundary.

2) Lithology within and surrounding the stockpile is identified as clay soil with sandy silt inserts to a depth of 25 meters without groundwater levels.

3) The lithological permeability value of underground hydrocarbon contaminated soils consists of clay soils with permeability values ranging from $1.2 \times 10-9 \mathrm{~cm} / \mathrm{sec}$ to $1.5 \times 10-6 \mathrm{~cm} / \mathrm{sec}$ and sandy silt with permeability values of $1.1 \times 10-8 \mathrm{~cm} /$ second $1.9 \times 10-6 \mathrm{~cm} /$ second. Based on the permeability values, it can be concluded that the lithology below the stockpile to be an aquitard.

4) TCLP test results from contaminated soil samples at the well drill points \# 1, \# 3, and \# 7 are below the TCLP-C value, and none have concentrations above TCLP-B.

5) Concentration value of $\mathrm{C} 6-\mathrm{C} 9$ fraction at test point \# 4 at 9 meters depth and C10-C36 fraction at test point \# 2 well point at 9 meters and 10.5 meters depth, and test point \# 7 at a depth of 4.5 meters between TK-A and TK-B values, therefore, contaminated soil samples at that point are categorized as Category II B3 waste and at other points classified as non-B3 waste. From the simulation of the distribution of B3 waste, the category 2 B3 waste volume is estimated at $127,500 \mathrm{~m} 3$.

6) Future allotment of the stockpile site is intended as an industrial area, implying receptors at risk of exposure to TPH contamination through ingestion, inhalation, and dermal contact. The SSTL value obtained from the calculation of Risk-Based Corrective Action is 3,19\%, with all drill points in the site area having a TPH concentration below the SSTL value.

7) The results of the identification of TPH concentrations indicate that the distribution of TPH concentrations is relatively high on the surface of the contaminated landfill. Clay soils located under piles have a permeability value of $1 \times 10-6 \mathrm{~cm} / \mathrm{sec}$, so that it can be concluded that the mobility of TPH from the surface into the soil is relatively low.

8) A landfill "cap" constructed on top of the hazardous waste stockpile is built with a fill-only method, leveling the hazardous waste stockpile height. A slope of 1:4 of the cap is a pertinent design feature to ensure that rainfall will be efficiently channeled into the surrounding drainage infrastructure.

\section{CONFLICT OF INTEREST}

The authors declare no conflict of interest.

\section{AUTHOR CONTRIBUTIONS}

All authors have contributed equally to the undertaking and publication of this study. All authors have approved the final version.

\section{REFERENCES}

[1] American Society of Testing and Materials, Standard Guide for Risk-Based Corrective Action Applied at Petroleum Related Sites, E1739-95, West Conshohocken, Pennsylvania, 1995.

[2] C. W. Fetter, Textbook of Applied Hydrogeology, 4th Edition, University of Wisconsin, Oshkosh, 2001.

[3] American Petroleum Institute, Risk-Based Methodologies for Evaluating Petroleum Hydrocarbon Impacts at Oil and Natural Gas E\&P Sites, United States of America, 2001.

[4] Indonesian Ministry of Environmental and Forestry, Government Regulation No. 101 Year 2014 Regarding Hazardous and Dangerous Waste Management, Special Capital City of Jakarta, 2014.

[5] Indonesian Ministry of Environmental and Forestry, Government Regulation No. 63 Year 2016 on Engineering Procedures for Dangerous and Hazardous Waste Landfills, Special Capital City of Jakarta, 2016.

[6] United States Environmental Protection Agency, Exposure Factors Handbook, National Center for Environmental Assessment, Office of Research and Development, US Environmental Protection Agency, Washington DC, 1999

[7] ASTM International, Standard Guide for Risk-Based Corrective Action, United States of America, 2004.

[8] S. C. Walpole et al., "The weight of nations: An estimation of adult human biomass," BMC Public Health, vol. 12, p. 439, 2012.

[9] Total Petroleum Hydrocarbon Criteria Working Group Series, Volume 5: Human Health Risk-Based Evaluation of Petroleum Contaminated Sites: Implementation of the Working Group Approach, Total Petroleum Hydrocarbon Working Group, Amherst Scientific Publishers, Amherst, Massachusetts, 1999.

[10] D. Vorhees and C. L. Butler, "Calculation of human health risk-based screening levels (RBSLs) for petroleum," Petroleum Engineering Journal, pp. 1-12, Universitat de Girona: Chelmsford, Massachusetts, 1999.

Copyright (C) 2021 by the authors. This is an open-access article distributed under the Creative Commons Attribution License, which permits unrestricted use, distribution, and reproduction in any medium provided the original work is properly cited (CC BY 4.0).

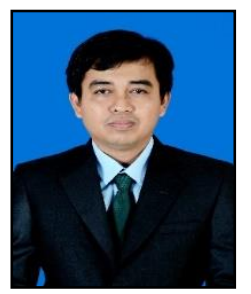

I Made Wahyu Widyarsana is a lecturer in the Undergraduate Environmental Infrastructure Engineering Program and the Master of water supply, Sanitation Infrastructure and Management Program of the Civil and Environmental Engineering Faculty at Bandung Institute of Technology (ITB). He was appointed as a civil servant (PNS) lecturer as per 2014. He is educated at Bandung Institute of Technology throughout his undergraduate to his Doctorate.

His education was done at ITB with a scholarship from ITB, and he obtained a Doctorate in 2011. In 2018, he was also awarded the professional practitioner engineering degree (Ir.) after completing his studies in the ITB engineer professional education program.

Since 2014, Wahyu has held various positions and responsibilities which include, among others, the Head of Environmental Engineering ITB Studio and Computer Room (2015-2019), Head of Environmental Engineering ITB Reading Room (Library) (2015-2019), Financial Manager at Solid Waste and Hazardous Waste, Environmental Engineering ITB Laboratory, and the Secretary of the Air and Waste Management Expertise Group. He currently serves as the Head of the Faculty of Civil and Environmental Engineering -ITB Solid Waste and Hazardous Waste Laboratory (2020-present). Dr. Ir. I Made Wahyu Widyarsana, ST. MT. teaches a variety of subjects in the Faculty of Civil and Environmental Engineering ITB, including Engineering Drawing, Solid Waste Management, Solid Waste Management, Landfill Pre-Design, Solid Waste Management System, Solid Waste Design, Environmental Engineering Design, Solid Waste System Planning, Water Infrastructure Planning, and Sanitation Studio), and Engineering Practices. $\mathrm{He}$ is also actively involved as chairman of the Environmental Infrastructure Engineering Bachelor Trial, guiding students in practical work courses, seminars, and final assignments. In addition to teaching at ITB, he frequents as a guest lecturer at many different universities and a trusted adviser in the Education and Training Center within the Indonesian Ministry of Public Works and Public Housing (PUPR). He is also heavily involved in applied research and professional activities as a professional planning consultant, resource person in various workshops, FGDs, technical guidance, symposiums, and seminars in the fields of planning, management, and technology development and human resource development in the field of waste and hazardous waste, both for government and non-government, including providing input for the development of norms, standards, 
guidelines, and policies, especially in the field of waste and hazardous waste in Indonesia.

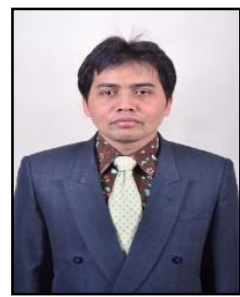

Sukandar is a lecturer in the undergraduate, graduate, and doctoral programs at the Environmental Engineering Study Program, Faculty of Civil and Environmental Engineering, Bandung Institute of Technology (ITB). His undergraduate and master's education was done at ITB before obtaining his doctorate in Japan at Okayama University.

Sukandar is the head of the Hazardous Waste Laboratories and is responsible for the breadth of Solid and hazardous waste research was done within the Environmental Engineering program. Sukandar specializes in the technology and management of solid and hazardous waste. With his chemistry background, Sukandar, outside of his teaching at ITB, is a trusted advisor to and resource person in the Indonesian environmental landscape, where he is a sought professional both by the Indonesian government and many independent associations, providing his expertise for the development of regulations and policies in the field of waste and hazardous waste in Indonesia. On-campus, he is a member of the Solid Waste and Air Pollution Research Group, holding the position as the Head of the Hazardous Waste Laboratory. He is also very active in environmental air pollution as his doctoral thesis focused on researching chemical stabilizers through the characteristics and bonds of fly ash.
From 2002 to 2006, Sukandar was the head of The Okayama Commissariat Indonesian Student Association, where he acted as the main representative of the Indonesian students in Japan. He is part of both the Japan Solid Waste Management Expert Society and the Indonesian Solid Waste Association, where he is continually providing his inputs. In 2019, Sukandar was the recipient of the Satyalancana Karya Satya award, bestowed by the Indonesian President for his consistent performance as a lecturer. He has continuously shown skill, discipline, and loyal devotion to his profession.

Sukandar is a known contributor in the Indonesian solid waste landscape as he was notably the expert resource for the Hazardous Waste Management Regulation issued by the West Java government. Throughout his career, he has also managed many waste management projects under his Team Lead role in ITB's Research Group, LAPI, where he has contributed his expertise to since 2009 .

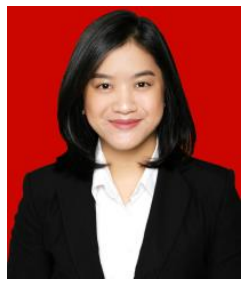

Windy Chyntia Dewi is an environmental engineering graduate with an affinity for sustainable environmental processes and design. Throughout her undergraduate degree, she was an assistant for the Solid Waste Management class and focused her research on Hazardous Waste Management. She seeks to one day sharpen her research within the field of environmental sustainability. 